\title{
IS BRANDENBURG'S SPIRIT STILL ALIVE? A PERSPECTIVE OF THE GREEK ANTI-RACIST LAW
}

\begin{abstract}
This Article analyzes the issue of hate speech limitations under the scope of both the Brandenburg Test and the Greek anti-racist Law. Although the Brandenburg doctrine has been criticized, especially with regard to its being applied to the phenomena of racism or xenophobia, its standards can also be detected in the Greek anti-racist Law, which has been recently amended. This Article examines the magic words "imminence", "public order", and "incitement to actions" and concludes that mere utterance of racist rhetoric is not punishable. Greek jurisprudence seems to be in line with the Brandenburg principles, tolerating inflammatory words that are harmless to social harmony and peace. This Article further suggests that, for public order to be endangered by hate speech, an in concreto analysis of the surrounding circumstances is necessary. In sum, Brandenburg helps Greek legal thought to understand the dynamic of the disturbance of public order through the "clear and present danger" perspective, while the Greek anti-racist Law offers an example of when and how hate speech may be deemed as an incitement not only to lawless action, but also to actions of hatred and discrimination.
\end{abstract}

\section{Keywords}

Hate speech - Brandenburg Test - Racism - Freedom of expression - Greek anti-racist law

\footnotetext{
* PhD in Law, National and Kapodistrian University of Athens, 2011.
} 


\section{INTRODUCTION}

The organizer of a Greek nationalistic rally telephones a television reporter and invites him to the meeting place. When the reporter and a cameraman arrive, he makes the following statement about refugees and immigrants coming from Turkey to the Greek islands: "We're not a revengent [sic] organization, but if our Prime Minister, our Parliament, our Supreme Court, continue to suppress the Greek habitants of our islands in favour of these trashy immigrants, it's possible that there might have to be some revengeance [sic] taken"1 ${ }^{\prime 1}$ Some decades ago, in the Cincinnati, Ohio, area, a Ku Klux Klan leader (Brandenburg) made a similar statement; Brandenburg had telephoned an announcer-reporter on the staff of a Cincinnati television station and invited him to come to a Ku Klux Klan rally to be held at a farm in Hamilton County; his harshly critical speech advocating, inter alia, violent means of action was filmed and subsequently shown on local and national television.

According to Lynd, " $[\mathrm{t}]$ he speech created no conceivable present danger. It was a pseudo-event, designed to exploit the media by generating free publicity" ${ }^{2}$. Indeed, the surrounding circumstances were reminiscent of a staged ancient Greek drama where twelve hooded figures, some carrying firearms, gathered around a burning cross, muttering words of racial hatred and veiled threats such as: "This is what we are going to do to the niggers"; "A dirty nigger"; "Send the Jews back to Israel"; "Let's give them back to the dark garden"; "Bury the niggers"; "We intend to do our part"; "Freedom for the whites"; and "Nigger will have to fight for every inch he gets from now on" ${ }^{\prime 3}$. Brandenburg, the organizer of the racist

${ }^{1}$ Inspired by the facts of Brandenburg v. Ohio, 395 U.S. 444 (1969), at 446. For a similar situation in Japan, in 2012, see Craig Martin, Striking the Right Balance: Hate Speech Laws in Japan, the United States, and Canada, "Hastings Constitutional Law Quarterly" 2018, vol. 45, p. 455, 461 (referring, inter alia, to a videotaped anti-Korean rally " $[\mathrm{w}]$ hich featured a young girl screaming that Koreans should be massacred, among other things").

2 Staughton Lynd, Brandenburg v. Ohio: A Speech Test for All Seasons, "The University of Chicago Law Review" 1975, vol. 43, pp. 151-152.

${ }^{3}$ Brandenburg v. Ohio, 395 U.S. 444 (1969), at 446 n.1. See also Susan M. Gilles, Brandenburg v. State of Ohio: An Accidental, Too Easy, and Incomplete Landmark Case, "The Capital University Law Review" 2010, vol. 38, p. 517. 
rally, also made in front of 11 hooded figures the following statement: "We are marching on Congress July the Fourth, four hundred thousand strong. From there we are dividing into two groups, one group to march on St. Augustine, Florida, the other group to march into Mississippi. Thank you".

Brandenburg was convicted under the Ohio Criminal Syndicalism Act for "advocat[ing] ... the duty, necessity, or propriety of crime, sabotage, violence, or unlawful methods of terrorism as a means of accomplishing industrial or political reform". But the US Supreme Court acquitted Brandenburg, holding that since the statute at issue, by its words and as applied, purports to punish mere advocacy, on pain of criminal punishment, it falls within the condemnation of the First Amendment which protects freedom of speech. So, the Court had the chance to establish a test protecting all advocacy other than "incitement to imminent lawless action" ${ }^{4}$.

The Brandenburg Court essentially required that the state must prove, "(1) intent to incite another; (2) to imminent violence; and (3) incitement in a context that makes it highly likely that such violence will occur"

Respectively, the Greek anti-racist Law No 927/1979 (Article 1(1)) ${ }^{6}$ penalizes intentional public incitement to acts or activities which may result in discrimination, hatred or violence against individuals or groups of individuals defined by reference to race, colour, religion, descent, national or ethnic origin, sexual orientation, gender identity, or disability. This or disability. In particular, according to Article 1 (1) of the Greek Law No 927/1979 on punishing acts or activities aiming at racial discrimination, "Anyone, who publicly incites, provokes, or stirs, either orally or through the press, the Internet, or any other means, acts of violence, discrimination or hatred against a person or group of persons or a member of such a group defined by reference to race, colour, religion, descent or national or ethnic origin, sexual orientation, gender identity, or disability, in a manner that endangers the public order and exposes the

${ }^{4}$ Brandenburg v. Ohio, 395 U.S. 444, 449 (1969).

5 Sic Lyrissa Barnett Lidsky, Brandenburg and the United States' War on Incitement Abroad: Defending a Double Standard, "Wake Forest Law Review" 2002, vol. 37, pp. 1009, 1018. See also Gilles, supra note 3, at p. 522 (listing several other scholars' views).

${ }_{6}^{6}$ As amended by Laws 2910/2001, 4285/2014 and 4491/2017. 
life, physical integrity, and freedom of persons defined above to danger, will be punished by imprisonment of from three months to three years and a fine of $€ 5,000$ to $€ 20,000 "$.

The above legislative action took place first in compliance with the fundamental obligations laid down in the International Convention on the Elimination of All Forms of Racial Discrimination (CERD, 21 December 1965; entered into force Jan. 4, 1969) ${ }^{7}$ and, subsequently, in compliance with European Council Framework Decision 2008/913/ JHA of 28 November 2008 "on combating certain forms and expressions of racism and xenophobia by means of the criminal law".

It is worth noting here that, before its crucial amendment in 2014, the Greek antiracist Law, Section 2, covered the expression in speech, via the press, in writings, by pictures or by any other means of any ideas offensive to an individual or a group of individuals by virtue of their racial or ethnic origin or their religious affiliations. This section was abolished by the subsequent Law No 4285/2014.

In this article, we will examine whether the Greek legal system approves of (or not) the Brandenburg ideas in the light of the amended Greek anti-racist Law. It should be observed that the underlying values are quite similar to both US and Greek legal schemes. Bearing this in mind, we will venture to explicate the scope of the Greek anti-racist Law by employing the Brandenburg standards. At the same time, this comparative quest may also offer an opportunity to justify Brandenburg in terms of policy, since it has been suggested that Brandenburg failed to ground its standard in any articulated vision of the First Amendment ${ }^{8}$. It

7 See particularly Article 4 of the CERD. This the USA ratified that convention was ratified by the USA only in 1994; however, the United States took a reservation to Article 4 , noting that it would not accept any obligation that could limit the extensive protections for freedom of expression, assembly, and association guaranteed in the U.S. Constitution (Japan registered also the same reservation; see Martin, supra note 1, at p. 472, 476-77). But this proviso does not, prima facie, exclude the United States from establishing a ban on racialized hate speech. See hereto Rory K. Little, Hating Hate Speech: Why Current First Amendment Doctrine Does Not Condemn a Careful Ban, "Hastings Constitutional Law Quarterly" 2018, vol. 45, pp. 577, 579. For the progress in implementing CERD’s provisions, see analytically Periodic Report of the United States of America submitted to the Committee in June 2013.

${ }^{8}$ See, e.g., Gilles, supra note 3, at p. 526. 
is stated, moreover, that "[b]ecause of Brandenburg's brevity, important questions remained about the precise scope of its holding" ${ }^{\prime \prime}$. Furthermore, Brandenburg has been taking the blame from many scholars on the basis that it is an incomplete landmark case failing to define the key terms of its test (imminence, likelihood, types of speech etc.) ${ }^{10}$. Yet, it can be contested that the Brandenburg Court crafted its principles based on vague legal concepts such as "incitement", "imminence", and "likelihood". In this way the Brandenburg Court, even though accidentally, was brought into line with Roman-law (and therefore Greek) legal tradition where the judicial "in concreto" definition of vague legal concepts (e.g., endangerment of public order) ensures the effective administration of justice. Kobil, for example, argues that Brandenburg is relatively easy to apply and "is remarkable for its clarity"11. Through the above definition, the judge can accomplish the right balance between freedom of expression and equality rights ${ }^{12}$. In essence, the judge, in accordance with the principle of proportionality, considers whether the very essence of the right of freedom of speech is impaired and whether the restrictions arising from equality rights pursue a legitimate aim and are proportionate ${ }^{13}$. It should be noted, though, that vague legal terms must be used sparingly in

${ }^{9}$ Chris Montgomery, Can Brandenburg v. Ohio Survive the Internet and the Age of Terrorism: The Secret Weakening of a Venerable Doctrine, "Ohio State Law Journal" 2009, vol. 70, pp. 141, 154.

10 See, inter alia, Martin H. Redish, Advocacy of Unlawful Conduct and the First Amendment: In Defense of Clear and Present Danger, "California Law Review" 1982, vol. 70, pp. 1159, 1175; Gilles, supra note 3, at p. 528 et seq.

${ }^{11}$ Daniel T. Kobil, Advocacy on Line: Brandenburg v. Ohio and Speech in the Internet Era, "University of Toledo Law Review", Volume 31, 2000, p. 227, 235-36. See also David Crump, Camouflaged Incitement: Freedom of Speech, Communicative Torts, and the Borderland of the Brandenburg Test, "Georgia Law Review Association”, Volume 1, Issue 74, 1994 (noting that " $[\mathrm{t}]$ he Brandenburg formula is clear. This is why Brandenburg is a sound protection of the freedom of speech, and it is why its test has endured".

${ }^{12}$ For that balance, cf. also Martin, supra note 1, at 481. Still, it is contended that, contrary to Greek case law, in U.S. law, priority is given to freedom of speech, Christina Vrettou, The Sharp Criticism As A Constitutional Right (in Greek) 8 (2014), and the references cited therein.

${ }^{13}$ The proportionality analysis is found also in the Oakes test of the Canadian jurisprudence, R. v. Oakes, [1986] 1 S.C.R. 103 (Can.). On the contrary, the United States has adopted differentiated levels of scrutiny; see hereto Martin, supra note 1, at p. 500. 
criminal matters. As Little notes, "[B]road grants of discretion in statutory language should be avoided"14.

In particular, part I of this Article examines Brandenburg's scope in relation to hate speech and tries to link Brandenburg with the Greek anti-racist Law. Part II analyzes the incitement-prerequisite, which is fundamental for both American and Greek law, and searches for those variables that may convert an abstract or doctrinal idea to an advocacyincitement of lawless action. Part III considers the problem of endangering the public order by uttering hate speech. This analysis includes the admission that American jurisprudence also takes into consideration public order policies and illustrates those factors that create direct and imminent danger to the social peace. The Article ends with the author's conclusion.

\section{The Scope of Brandenburg Test in Relation to Hate SPEech Restrictions on Freedom OF EXPRESSION}

The abovementioned illustration poses a question about the reproachable character (and its limits) of statements embodying discriminating or hate speech. The answer to that question lies in the Brandenburg Test as well as in the Greek antiracist Law and relates to freedom of expression on the one hand and equality rights on the other. However, the grounds of the Brandenburg judgment raise doubts on the compatibility of the Brandenburg Test with hate speech characteristics.

\section{Hate Speech Issues: Freedom of Expression V. EOQUALITY RIGHTS}

Professor Martin acknowledges that hate speech even undermines constitutional rights; but, he continues, "to suppress hate speech similarly risks causing significant harm to constitutional rights and democratic

${ }^{14}$ Little, supra note 7, at p. 587. 
principles"15. Worse still, hate speech limitations may lead to the opposite result by contributing to a feeling in public opinion that the enemies of democracy are victims of censorship. Here, a reasonable balance between equality rights and freedom of expression serves to be a prerequisite for ensuring the Rule of $\mathrm{Law}^{16}$. Professor Martin puts emphasis on that, suggesting that "[i]t is crucially important to recognize that hate speech laws can and should embody equality rights - that they ought to be crafted with a view to fulfilling the promise of constitutional equal protection rights"17.

On the other hand, the Greek Supreme Court itself embraces the above same principles. In a case regarding an anti-Semitic book, the Court (a) recognized freedom of expression as a principal pillar of a democratic society, (b) expressed the view that a democratic society is characterized by pluralism and tolerance, (c) accepted that, in a tolerant democratic society, even extreme anti-democratic views are allowed, and (d) embraced the opinion that the Greek anti-racist Law's provisions restricting the freedom of speech shall be construed narrowly and strictly ${ }^{18}$.

In the same vein, the European Court of Human Rights, in Handyside, ruled that freedom of expression

${ }^{15}$ Martin, supra note 1 , at p. 456.

16 See also Charalambos Anthopoulos, Ban On Racist Speech As a Constitutional Problem (in Greek), EEEurD 2001, 31; Athanasios Chouliaras, Criminalization of Hate Speech in a Liberal and Democratic Rule of Law: The Situation in Greece (in Greek), NoB 2017, 1222. But see Martin, supra note 1, at p. 458, 481 (noting that the American approach does not seem to recognize the constitutionalist character of harms that hate speech legislation seeks to address). To that effect, see also John C. Knechtle, When to Regulate Hate Speech, "Pennsylvania State Law Review", Volume 110, 2016, p. 539, 552, 563 (noting that the concept of human dignity was not incorporated into the federal Constitution).

17 Martin, supra note 1, at p. 521.

${ }^{18}$ Greek Supreme Court (Plenary Session) No 3/2010; (the Court acquitted the writer of a book which expressed ideas that were offensive to Jews); Criminal Court of Rethimnon No 2383/2015, PoinChr 2017, p. 450, at para. 19, 66.19, 66 (the accused for violating Article 2 of the Greek antiracist Law on denial of crimes of war was a German Professor and had written a book for the "fighting in Crete" during the World War II; the book, which was also released in Greece, contained references about atrocities committed by Greek fighters against the German paratroopers). See also Vejdeland and Others v. Sweden, 9 February 2012, § 53, ECHR; Lopes Gomes Da Silva v. Portugal, 28 September 2000, § 30, ECHR. 
[i]s applicable not only to "information" or "ideas" that are favourably received or regarded as inoffensive or as a matter of indifference, but also to those that offend, shock or disturb the State or any sector of the population. Such are the demands of that pluralism, tolerance and broadmindedness without which there is no "democratic society"19.

But the same Court, in another case, took a specific reservation as regards "hate speech":

[ $\mathrm{t}$ ]olerance and respect for the equal dignity of all human beings constitute the foundations of a democratic, pluralistic society. That being so, as a matter of principle it may be considered necessary in certain democratic societies to sanction or even prevent all forms of expression which spread, incite, promote or justify hatred based on intolerance (including religious intolerance), provided that any "formalities", "conditions", "restrictions" or "penalties" imposed are proportionate to the legitimate aim pursued ${ }^{20}$.

Chouliaras, finally, stresses that the State should not remain neutral regarding minimum fundamental principles ${ }^{21}$.

${ }_{19}$ Handyside v. The United Kingdom, 7 December 1976, § 49, ECHR. In that case the applicant was the publisher of a book which urged young people at whom it was directed to take a liberal attitude in sexual matters.

${ }^{20}$ Gündüz v. Turkey, 4 December 2003, § 40, ECHR. (the applicant made very critical statements concerning democracy in a television program).also Papacharalambous, supra note 19, at 210 (noting that Handyside acquis and its absolute are not self-evident anymore). For an analogous limitation-approach of the Japanese Supreme Court, based on balancing of interests, see Martin, supra note 1, at 479. Cf. also Charis Papacharalambous, Legislating About Hate - The Paradigm of the anti-racist Law No 4285/2014 (in Greek), NoB 2016, 209, at p. 210 (noting that Handyside acquis and its absolute are not self-evident anymore; in general, the writer in his article: a) distinguishes between verbal violence and racist speech, b) points out the harms that verbal hate causes, c) puts emphasis on the "silencing" effect of hate rhetoric on its victims, d) notes that hate speech endangers public order because it does not help people communicate freely, e) criticizes the Greek antiracist law as regards the fact that the Law requires specific danger, which is most favorable to the offender, and $f$ ) contents that hate rhetoric should be punishable as such).

${ }^{21}$ Chouliaras, supra note 16, at p. 1223-24 (referring to a moderate form of 'militant democracy'; but, in a judgment of 7 November 2007 (no. 235/2007; BOE-T-2007-21161), the Spanish Constitutional Court noted that Spain did not have a "militant democracy"; see for the latter Perinçek v. Switzerland, 15 October 2015, § 97, ECHR) concerning public denial 


\section{The Application of Brandenburg Test to Hate SPEech}

In Brandenburg, the US Supreme Court embraced a generously tolerant attitude towards inflammatory speech in the light of the First Amendment according to which, "[C]ongress shall make no law ... abridging the freedom of speech"22. But, as Little puts it, the "plain language" of the First Amendment has never been interpreted to be absolute ${ }^{23}$. Therefore, speech is unprotected under Brandenburg only when it (a) advocates imminent lawless action, and (b) is likely to produce imminent lawless action $^{24}$. In contrast, CERD is much more severe since it condemns even the dissemination of ideas based on racial superiority or hatred (Article 4).

But, while the Greek Law explicitly protects interests against racial discriminating speech, the Brandenburg principles primarily relate to speech advocating the necessity of crime or violence for the overthrow of the government ${ }^{25}$. Although the accused had uttered racist speech, the subject matter of the judicial scrutiny constituted incitement to violence against government. According to Gilles, Brandenburg focused on the wrong speech:

to the Armenian genocide). For a distinction between militant and pluralist democracy, see also Anthopoulos, supra note 16, at 51-52.

${ }^{22}$ According to Professor Gunther, the Brandenburg test is "the most speech-protective standard yet evolved by the Supreme Court", Gerald Gunther, Learned Hand and the Origins of Modern First Amendment Doctrine: Some Fragments of History, "Stanford Law Review" 1975, vol. 27, p. 755. Equally, Article 14(1) of the Constitution of Greece declares that " [e]very person may express and propagate his thoughts orally, in writing, and through the press in compliance with the laws of the State".

${ }^{23}$ Little, supra note 7, at p. 583-84 (citing, e.g., Miller v. California, 413 U.S. 15, 24 (1973), which held that obscenity is simply "not speech"). See also Virginia v. Black, 538 U.S. 343 (2003) at p. 358. But see Charis Papacharalambous, Legislating About Hate - The Paradigm of the anti-racist Law No 4285/2014 (in Greek), NoB 2016, 209,supra note 20, at p. 211 (referring to a "quirky absolutizing [sic] of freedom of speech).

24 See Lynd, supra note 2, at p. 164.

25 See Brandenburg v. Ohio, 395 U.S. 444 (1969) at p. 444-45 (referring to advocacy of violence "as a means of accomplishing ... political reform"). Cf. also Gilles, supra note 3, at p. 530; Knechtle, supra note 16, at p. 548 (referring to threats against the government). 
[W] hen reading the facts of Brandenburg, the troubling speech is not Brandenburg's silly call for revenge on Congress ${ }^{26}$; it is rather the speech of "a burning, fiery cross" and the Klan's racist threats to "[b]ury the niggers" 27. The Brandenburg decision feels incomplete because it never addresses this hateful, threatening speech ${ }^{28}$.

Professor Martin also comments that "[W]hile he [Brandenburg] and other members of the Klan had been recorded on film making virulently hateful statements about African Americans and Jews that was not the primary legal grounds for the prosecution" ${ }^{29}$.

So, Brandenburg laid down a test designed to protect political advocacy. Nevertheless, its principles protect freedom of speech in general and, therefore, can apply also to racist speech. Gey's words also suggest Brandenburg's universality:

The restrictions on the government that are embedded in the Brandenburg paradigm are not just functions of the political speech context in which Brandenburg arose, nor can it even be said that the spirit of the Brandenburg paradigm is anchored in the First Amendment alone. The Brandenburg paradigm is not just an assertion of the First Amendment or free speech

${ }^{26}$ But see also Crump, supra note 11, at p. 4 (referring to 'revengeance" [sic] against ethnic minorities).

27 Brandenburg v. Ohio, 395 U.S. 444, 445-46 (1969).

${ }^{28}$ Gilles, supra note 3, at p. 530. Vindication occurred subsequently through the Black case, where three persons were accused for violation of a statute of Virginia State banning cross burning in the property of another or public places with intent to intimidate or place others in fear of bodily harm: "[a] State, consistent with the First Amendment, may ban cross burning carried out with the intent to intimidate", Virginia v. Black, 538 U.S. 343 (2003), at p. 347. Similar expressions of racist nature, such as "'the niggers are not human beings, they are animals" or "just take a picture of a gorilla, man, and then look at a nigger, it's the same body structure and everything, man, flat forehead and all kinds of things", were considered by the ECHR (as obiter dictum) to be "[m]ore than insulting to members of the targeted groups and did not enjoy the protection of Article 10 [of the Convention on Human Rights, regarding freedom of expression]", Jersild v. Danemark, 23 September 1994, § 35, ECHR. (the appellant was a journalist who interviewed three members of a xenophobic and racist group making derogatory statements about racial minorities and immigrants).

${ }^{29}$ Martin, supra note 1, at p. 485, 522. 
rights, but rather a statement about the very nature of constitutional democracy itself ${ }^{30}$.

Still, it is strongly contested that racist speech merits special treatment ${ }^{31}$. Martin expresses doubts about applying the Brandenburg test to hate speech $^{32}$. While, he continues, Brandenburg refers to incitement to imminent lawless action, hate speech is reproachable for primarily causing broader harm on an individual and collective basis, and, more importantly, for injuring " $t$ ] he values of tolerance and equality within the society at large" ${ }^{\prime \prime 3}$.

Furthermore, it seems, prima facie, that Brandenburg regulates the abstract advocacy of violence or revolution ${ }^{34}$, so that its test should be construed as proscribing the incitement only to violence. Therefore, Brandenburg makes clear " $[\mathrm{t}]$ hat no abstract, ideological, emotional, or otherwise intangible harms would suffice to justify the regulation of advocacy"35. But expressions of racism or xenophobia may not always constitute signalling instruments of violence. In this regard, it must be borne in mind that the Greek anti-racist Law explicitly refers to incitement to actions or activities that may result not only in violence, but also in discrimination or hatred (Article 1(1)). For example, advising private employers not to provide immigrants access to the labour market or inciting private restaurants to deny service to black people are in principle within the Greek Law's scope. That applies equally to advocated hateful acts (e.g. intimidation). The Brandenburg test refers to 'lawless action' in

\footnotetext{
${ }^{30}$ Steven G. Gey, The Brandenburg Paradigm and Other First Amendments, "University of Pennsylvania Journal of Constitutional Law" 2009-2010, vol. 12, issue 4, pp. 971, 1050.

31 See, e.g., Chouliaras, supra note 16, at p. 1226-27 (noting that racist rhetoric violates the constitutionally protected dignity of human life).

${ }^{32}$ Martin, supra note 1, at p. 486.

33 Ibid.

34 See also S. Elizabeth Wilborn Malloy \& Ronald J. Jr. Krotoszynski, Recalibrating the Cost of Harm Advocacy: Getting Beyond Brandenburg, "William and Marry Law Review", Volume 41, Number 4, 2000, p. 1159, 1168; Chidiebere T. Madu, Killer Cartoons: Islamophobia, Depictions of the Prophet Muhammad, and the Possible Limitations of Free Speech, "First Amendment Law Review" 2016, vol. 14, issue 3, 2016, pp. 489, 510(“[s]peech which advocates for violence").

${ }^{35}$ Gey, supra note 30, at p. 984.
} 
general, but its subject matter was an Act that punishes persons who "advocate or teach the duty, necessity, or propriety" of violence "as a means of accomplishing industrial or political reform" ${ }^{\prime 36}$.

Nevertheless, the Brandenburg Court acknowledges that previous decisions "[h]ave fashioned the principle that the constitutional guarantees of free speech and a free press do not permit a State to forbid or proscribe advocacy of the use of force or of law violation except where such advocacy is directed to inciting or producing imminent lawless action and is likely to incite or produce such action" ${ }^{\prime \prime 2}$. Here, the emphasis is given to the phrase "or of law violation"; this is a step that subsequent jurisprudence may take in order to adjust the Brandenburg doctrine about 'incitement to violence' to the idiosyncrasies of hate speech. And this step is easy to take because it does not undermine the basic principles of the Brandenburg decision. Besides, the Greek anti-racist Law refers to incitement to hateful acts and not just to incitement to hatred. Hateful acts may not always be violent, but they constitute unlawful conduct, while mere hatred is an internal movement of the human soul and cannot, for that reason, be equated with acts of violence. The government must regulate the external human relations and not internal emotions.

To this effect, Malloy \& Krotoszynski observe that "[i]f speech aims to facilitate a particular lawless act against a discrete victim or group of victims [such as racial or religious minorities], the government's claim of concern sounds far more plausible on its face" ${ }^{\prime 38}$. Similarly, the ECHR characteristically stresses in a case about the distribution of leaflets against homosexuality,

[i]nciting to hatred does not necessarily entail a call for an act of violence, or other criminal acts. Attacks on persons committed by insulting, holding up to ridicule or slandering specific groups of the population can be sufficient for the authorities to favour combating racist speech in the face of freedom of expression exercised in an irresponsible manner ${ }^{39}$.

\footnotetext{
36 Brandenburg v. Ohio, 395 U.S. 444, 448 (1969).

37 Ibid. at p. 447.

38 Malloy \& Krotoszynski, supra note 34, at p. 1197.

${ }^{39}$ Vejdeland and Others v. Sweden, 9 February 2012, § 55, ECHR. See also Féret v. Belgium,
} 16 July 2009, § 73, ECHR. 
Surely, though, it is difficult to rely on the Brandenburg test for the purpose of proscribing mere dissemination of racist ideas because here the prerequisite of incitement cannot be easily established.

So, Brandenburg remains good law for combating racism and xenophobia, bearing in mind that no distinct category for "hate speech" has yet been developed by American jurisprudence ${ }^{40}$. Besides, the US government emphatically points out in its report for the implementation of CERD that, "[w]e protect freedom of expression because the cost of stripping away individual rights is far greater than the cost of tolerating hateful words" ${ }^{41}$. In fact, the American system seems to privilege speech over equality ${ }^{42}$. Loewy adopts the proposition that "[s]peech cannot conflict with other values" and that "[p]eople have a right to voice an unpopular opinion, because the safeguards of the Constitution prevent the idea from being implemented" 43 .

Moreover, the same report on racism and xenophobia specifically quotes Brandenburg as a limited exception to freedom of expression:

Consistent with the First Amendment, we do not permit speech that incites imminent violence. This is a limited exception to freedom of expression, and such speech is only unlawful when it "is directed to inciting or producing imminent lawless action and is likely to incite or produce such action." Brandenburg v. Ohio, 395 U.S. 444, 447 (1969) ${ }^{44}$.

\footnotetext{
${ }^{40}$ Martin, supra note 1, at p. 483.
}

${ }^{41}$ U.S. Periodic Report for the Committee on Elimination of Racial Discrimination (CERD) (2013), at para. 50. Cf. also Gilles, supra note 3, at 520 (referring to Brandenburg's startling commitment to free speech); Arnold H. Loewy, A Dialogue on Hate Speech, "Florida State University Law Review" 2008, vol. 36, issue 1, pp. 67, 77.

${ }^{42}$ Martin, supra note 1, at p. 481 (noting that the Canadian example strikes a more balanced approach); Knechtle, supra note 16, at p. 539 (arguing that in the United States "free speech interests prevail"). See also Murdock v. Pennsylvania, 319 U.S. 105, 115 (1943) ("Freedom of press, freedom of speech, freedom of religion are in a preferred position").

43 Arnold H. Loewy, Free Trade in Ideas Is (or Ought to Be) Absolute for Adults, "BYU Law Rview" 2007, pp. 1585, 1585-87.

${ }^{44}$ U.S. Periodic Report for CERD (2013), at para. 51. Lowey also connects Brandenburg with Ku Klux Klan hate speech, Loewy, supra note 41, at p. 67 n. 4. 


\section{II. "INCITEMENT TO ACTION" AS ACOMMON COMPONENT OF BOTH BRANDENBURG TEST AND THE GREEK ANTIRACIST LAW}

In the context of setting the lines for the punishable character of hate speech, not only is the distinction between advocacy of abstract (hate) doctrine and advocacy of action important for the US law, but it is also important for the Greek law.

\section{A. Mere AdVocacy of Racist IDEOlogy IS NOT PUNISHABLE}

Contrary to the CERD's provisions, condemning all racist propaganda, US as well as Greek law do not ban racist or hate rhetoric per se. In particular:

\section{The Greek ANTI-RACISt LaW Reouires "INTEntional INCITEMENT"}

Before its amendment, Article 2 of the Greek Law did penalize the expression of ideas insulting individuals or groups of individuals only because of their race or national origin. Now, the Greek anti-racist Law explicitly refers to intentional incitement to actions or activities which may result in discrimination, hatred or violence. For that reason, Professor Papacharalambous acknowledges that now the Greek legislator "[e]xcessively maximizes freedom of expression" 45 . This means that the speaker must encourage others to inflict damage, commit a crime, swear and address vulgarities etc. and not just utter words that anger the listener. In this context, the mere utterance of a scientific opinion consisting of racist comments cannot be deemed as incitement to actions. Therefore, racist or xenophobic speech is not punishable as such, but

45 Papacharalambous, supra note 20, at 210. But see Maria Kaiafa-Gbandi, Criminal Punishment of Racist Speech, Racist Crimes and Racist Discrimination: Towards a Substantive Protection of Human Value (in Greek), PoinDik 2016, 97, 101 (describing, inter alia, the potential criminalization of mere expression of racist ideology as excessive). 
only because of its connection with lawless acts ${ }^{46}$. Such acts are, e.g., use of armed violence, damage to property, verbal abuse, and insult by act, intimidation, bullying, and threats ${ }^{47}$. In the Canadian case Whatcott, Justice Rothstein emphatically referred to the notion of 'hatred", which typically includes a component of viewing members of the target group as being inferior and unworthy of respect and inclusion within the broader community ${ }^{48}$. He further focuses on the hateful act of vilification which is common to hate propaganda and aims to "dehumanize members of the group, typically through the use of animal labels and metaphors" 49 .

The recent legislative reform in Greece is in line with the EU law but it seems to contradict the CERD's provisions, according to which "States Parties condemn all propaganda [...] which attempt[s] to justify or promote racial hatred and discrimination in any form" as well as "[States Parties] shall declare an offence punishable by law all dissemination of ideas based on racial superiority or hatred" (CERD, Article 4$)^{50}$. In other words, the Greek legislator does not criminalize the mere dissemination of ideas based on discrimination, racial hatred and the like. The relevant provisions of the Greek anti-racist Law do not ban the mere utterance of ideological disagreement, views about racial, national, ethnic or

${ }^{46}$ See also Bernard Schwartz, Holmes Versus Hand: Clear and Present Danger or Advocacy of Unlawful Action?, "Supreme Court Review", 1994, p.209, 217 (referring to the 'clear and present danger' test).

47 See also Charalambos Anthopoulos, Protection from Racism and Freedom of Information: A Constitutional Dilemma, Athens, 2000 (in Greek) P. 133; Chouliaras, supra note 16, at 1233 (referring to "acts of hate").

${ }^{48}$ Whatcott v. Saskatchewan Human Rights Tribunal, [2013] 1 S.C.R. 467 (Can.), at para. 42-43 (Distribution of flyers that promoted hatred against individuals on the basis of their sexual orientation).

${ }^{49}$ Ibid., at para. 45.

${ }^{50}$ However, it should be noted that the Greek anti-racist Law seems to go beyond CERD'S scope, because it protects not only persons of another race or color but also persons with different sex orientation as well as the disabled people. This is in line with ECHR's case law, according to which "discrimination based on sexual orientation is as serious as discrimination based on race, origin or colour", Vejdeland and Others v. Sweden, 9 February 2012, § 55, ECHR. Supportive to that also Maria Kaiafa-Gbandi, Criminal Punishment of Racist Speech, Racist Crimes and Racist Discrimination: Towards a Substantive Protection of Human Value (in Greek), PoinDik 2016, 97 supra note 45, at p. 103. 
cultural superiority, and disguised racist opinion ${ }^{51}$, but rather require an additional condition of incitement to specific actions or activities. For example, the mere message in social media, "I hate immigrants, homosexuals, Christians etc.", is not in principle punishable by the Greek Law. In a more general context, the U.S. Supreme Court held that "the mere dissemination of ideas-no matter how offensive to good taste-on a state university campus may not be shut off in the name alone of 'conventions of decency'" 52 .

\section{The Brandenburg Prereouisite for "INTEntional InCitement"}

The Brandenburg Court distinguishes abstract advocacy or teaching from action or preparing others for action53 and demands that the advocating speech be directed to inciting or producing imminent lawless action ${ }^{54}$. Previously, the US Supreme Court had pointed out that "[t]he essential distinction is that those to whom the advocacy is addressed must be urged to do something, now or in the future, rather than merely to believe in something" ${ }^{\prime 5}$. In this context, in Bond v. Floyd, the Court held that remarks supporting draft resisters were protected because they did not include express advocacy of illegal action ${ }^{56}$.

The above the Brandenburg statement has been read, furthermore, as stating an "intent to incite" requirement ${ }^{57}$. Therefore, Brandenburg protects the "accidental" inciter - the speaker whose language triggers

51 Anthopoulos, supra note 16, at p. 31.

${ }^{52}$ Papish v. Bd. of Curators Univ. of Mo., 410 U.S. 667, 670 (1973). That case related to distribution of a newspaper's issue which included a political cartoon depicting police officers raping the Statue of Liberty and the goddess of justice and an article with a title containing a vulgar expression.

${ }_{53}$ Marc Rohr, Grand Illusion: The Brandenburg Test and Speech That Encourages or Facilitates Criminal Acts, "Willamette Law Review" 2002, vol. 38, issue 1, pp. 8-9.

${ }^{54}$ Brandenburg v. Ohio, 395 U.S. 444 (1969) at p. 447.

55 Yates v. United States, 354 U.S. 298, 324-25 (1957) (leaders of the Communist Party were accused under the Smith Act which prohibited wilfully and knowingly conspiring to teach and advocate the overthrow of the government by force).

${ }_{56}$ Bond v. Floyd, 385 U.S. 116 (1966).

57 See Gilles, supra note 3, at p. 522-23; Rodney A. Smolla, Should the Brandenburg v. Ohio Incitement Test Apply in Media Violence Tort Cases?, "Northern Kentucky Law Review" Vol. 27, 2000, p. 1, 10. 
a riot, but who had no intent to incite such lawlessness ${ }^{58}$. Nevertheless, it should be noted that the Brandenburg test does not require intent to cause illegal results; it is sufficient that the offender intentionally created the dangerous situation ${ }^{59}$. Accordingly, in order for the Brandenburg test to apply, it is not required that the victim be identifiable or that the specific harm be intended ${ }^{60}$.

It must be borne here in mind that the advocated evil (discriminating, hateful, or violent acts) does not need to occur; it is sufficient that the inflammatory speech is likely to produce imminent lawless action. But, in NAACP v. Claiborne Hardware Co., the US Supreme Court considered whether unlawful action actually followed speech, holding that "[I]n this case, however.., the acts of violence [shots fired at a house, brick that was thrown through a windshield, damaged flower garden] ... occurred weeks or months after the ... speech ..."61. This authority, however, is not apposite for the purpose of drawing sufficiently firm conclusions because it concerned a civil suit for damages and that fact may explain the Court's "apparent requirement of a link between the speech and a resulting act of violence" 62 .

By the same token, the Greek anti-racist Law explicitly refers to intentional incitement to actions or activities which may result in discrimination, hatred, or violence. This means that the speaker must encourage others to inflict damage, commit crime, swear, and address vulgarities etc.

\section{Judicial ExCEPtions to the BRANDENBURG RULE ON "INCITEMENT TO ACTION"}

The US Supreme Court has made sporadic attempts to address the problem of hate speech without adopting the "incitement to action" criterion. These cases are as follows:

58 Gilles, supra note 3, at p. 523; Thomas Healy, Brandenburg in a Time of Terror, "Notre Dame Law Review", Volume 84, Issue 2, 2009, p. 655, 701-02.

59 See also Crump, supra note 11, at p. 42 (citing Weirum v. RKO General Inc., 539 P.2d 36 (Cal. 1975)).

${ }^{60}$ Brandenburg v. Ohio, 395 U.S. 444, 447 (1969); Crump, id.

${ }^{61}$ NAACP v. Claiborne Hardware Co. 458 U.S. 886, 928 (1982).

${ }^{62}$ Sic Rohr, supra note 53, at p. 928. 


\section{a) The Beauharnais CASE}

BeforeThe recent legislative reform in Greece is in line with the EU law, but it seems to contradict the CERD's provisions, according to which "States Parties condemn all propaganda [...] which attempt[s] to justify or promote racial hatred and discrimination in any form" as well as "[States Parties] shall declare an offence punishable by law all dissemination of ideas based on racial superiority or hatred" (CERD, Article 4$)^{63}$. In other words, the Greek legislator does not criminalize the mere dissemination of ideas based on discrimination, racial hatred, and the like suppresses and silences the voices of members of the target minority ${ }^{64}$.

Brandenburg, the US Supreme Court had upheld a "hate speech" criminal statute against constitutional attack ${ }^{65}$. The statute in question prohibited the publication of any "lithograph" that "exposes the citizens of any race, color, creed or religion to contempt, derision or obloquy" The Court affirmed Beauharnais's conviction based on the circulation of a leaflet with racist content against the black race. As Little points out, the Beauharnais Court "[e]ndorsed group protection on behalf of the individual - in other words, permissibly banning [sic] hateful speech of racial groups due to the harms that could befall individual members of the target group" ${ }^{\prime 67}$. However, it is doubted whether Beauharnais is still

${ }^{63}$ However, it should be noted that the Greek anti-racist Law seems to go beyond CERD'S scope, because it protects not only persons of another race or color, but also persons with different sex orientation as well as the disabled people. This is in line with ECHR's case law, according to which "discrimination based on sexual orientation is as serious as discrimination based on race, origin or colour", Vejdeland and Others v. Sweden, 9 February 2012, § 55, ECHR. Supportive to that also Maria Kaiafa-Gbandi, Criminal Punishment of Racist Speech, Racist Crimes and Racist Discrimination: Towards a Substantive Protection of Human Value (in Greek), PoinDik 2016, p. 97, 103.

${ }^{64}$ See, e.g., in Canadian jurisprudence R. v. Keegstra, [1990] 3 S.C.R. 697 (Can.), at p. 762-63. See also Onder Bakircioglu, Freedom of Expression and Hate Speech, 16 "Tulsa Journal of Comparative and International Law" 2008, vol. 16, issue 1, 2008, pp. 1, 11.

65 Beauharnais v. Illinois, 343 U.S. 250 (1952).

${ }^{66}$ Ibid., at p. 251.

${ }^{67}$ Little, supra note 7, at p. 592. Cf. also Papacharalambous, supra note 20, at p. 212, 214 (stressing the collective character of hate speech). 
good law ${ }^{68}$. Subsequently, the Seventh Circuit Court of Appeals, in a case about prohibiting the dissemination of anti-Jewish materials in the Village of Skokie, "expressed the strong view that Beauharnais was no longer good law in any event, given how the scope of both civil and criminal libel law had been narrowed by the Supreme Court in the intervening years"69. Martin explains this on the ground that Beauharnais did not "[c]reate a new category of less protected speech" but "it chose libel as the most convenient category"70; in other words, the Beauharnais Court suggested that " $[r]$ acist expression was analogous to, and indeed a species of, criminal libel, thus fitting the speech into the well-established category of defamation as an unprotected or lesser protected form of speech"71.

\section{b) The Chaplinsky CASe}

Relevant to hate speech is also the Chaplinsky case, where a Jehovah's Witness called a city marshal a "God damned racketeer" and "a damned Fascist" in a public place $^{72}$. The Chaplinsky Court put emphasis on whether fighting words "by their very utterance inflict injury"73. The last phrase, however, lends itself to different interpretations. For example, Papacharalambous emphasizes that racist words may cause 'silencing' to the targets, i.e., a self-limitation not to react out of fear ${ }^{74}$. On the contrary, the fighting words doctrine seems to relate only to "speech which by its very utterance provokes a hostile reaction" ${ }^{\prime 7}$. According to the Court, the Chaplinsky test is what men of common intelligence would understand would be words likely to cause an average addressee to fight ${ }^{76}$. As Martin notes, the Chaplinsky test "[h]as been significantly narrowed in

${ }^{68}$ See Erwin Chemerinsky, Constitutional Law: Principles and Polices, Third Edition, New York: Aspen Publishers 2006, p.1012.

${ }^{69}$ Colin v. Smith, 578 F.2d 1197, 1205 (7th Cir. 1978); see also Martin, supra note 1, at p. 487.

${ }^{70}$ Ibid., at p. 484.

${ }^{71}$ Ibid.

72 Chaplinsky v. New Hampshire, 315 U.S. 568, 569 (1942).

73 Ibid., at p. 572.

${ }^{74}$ Papacharalambous, supra note 20, at 212; see also Martin, supra note 1, at p. 456.

75 Madu, supra note 34, at p. 504.

76 Chaplinsky v. New Hampshire, 315 U.S. 568, 573 (1942). 
subsequent cases" to the extent that "[I]t is only language likely to provoke an immediate violent response that now comes within the category"77. Indeed, in Texas v. Johnson, the U.S. Supreme Court held that, for the fighting words doctrine to apply, the speech must be "[a] direct personal insult or an invitation to exchange fisticuffs"78. Accordingly, the Court rejected the state's argument that burning the United States flag could be construed as fighting words, Justice Brennan stating that " $[\mathrm{N}]$ o reasonable onlooker would have regarded Johnson's [burning of the flag]" as an insult meant for them ${ }^{79}$. In this regard, Lowey admits that the Chaplinsky test is limited only to face-to-face words ${ }^{80}$; according to him, "if [one man] writes a book or carries a sign that attacks homosexuals as the cause of all that is wrong in America, he could not be punished for his words [under the Chaplinsky test]" 11 . For the abovementioned reasons it is contended that the fighting words doctrine is "[n]othing more than a quaint remnant of an earlier morality that has no place in a democratic society dedicated to the principle of free expression" ${ }^{\prime 2}$.

Accordingly, inflammatory statements or expressions directed towards a religious, racial, ethnic, or other "targeted class" of individuals do not seem to be covered by the Chaplinsky test. However, Lawrence argues that, irrespective of falling into the traditional category of fighting words, racist insults should be deemed constitutionally unprotected because such speech "[i]s experienced [by the target of the speech] as a blow, not a proffered idea, and once the blow is struck, it is unlikely that dialogue will follow" ${ }^{\prime 83}$. Madu, in order to classify depictions of the Prophet Muhammad as fighting words worthy of censorship, expresses the view that,

77 Martin, supra note 1, at p. 486.

78 Texas v. Johnson, 491 U.S. 397, 409 (1989).

79 Ibid. See also Madu, supra note 34, at p. 505.

${ }^{80}$ Loewy, supra note 41, at p. 68.

${ }^{81}$ Ibid. (citing Gooding v. Wilson, 405 U.S. 518, 528 (1972)).

82 Stephen A. Gard, Fighting Words as Free Speech, "Washington University Law Review", Volume 58, Issue 3, 1980, p. 531, 536.

${ }^{83}$ Charles R. Lawrence III, If He Hollers Let Him Go: Regulating Racist Speech on Campus, "Duke Law Journal", 1990, p. 431, 452; see also Gey, supra note 30, at p. 1048. 
[s]tate officials could argue that these depictions are directly targeted at all members of the Muslim community. If we consider these depictions to be Islamophobic speech because of their "blasphemous" nature, it follows that demonizing and ridiculing Islam and its believers - the apparent goal of Islamophobia - is analogous to an "invitation to exchange fisticuffs" in Justice Brennan's view ${ }^{84}$. Therefore, Muslims, as a class, are the direct target of these fighting words ${ }^{85}$.

\section{C) THE R.A.V. CASE}

In R.A.V., Justice Stevens noted that " $[\mathrm{t}]$ hreatening someone because of her race or religious beliefs may cause particularly severe trauma or touch off a riot" ${ }^{\prime 86}$. In the abovementioned case, two young men had erected a burning cross (symbol of hate) in the yard of the house of an African-American family. The Court, however, relying on the fighting words doctrine, was mainly concerned about "the reaction that such words would provoke, rather than on hate speech per se, and the nature and extent of the harm it would cause to the minorities it targeted"87.

Also, the Mitchell decision on equal protection is relevant in this context, noting that " $[\mathrm{b}]$ ias-inspired conduct is thought to inflict greater individual and societal harm" than the same conduct without the bias ${ }^{88}$.

\section{Critioue}

Behind the normative choice, made by the US and Greek legal orders, a marketplace approach to speech is hidden. As Justice Holmes put it,

[t] he ultimate good desired is better reached by free trade in ideas - that the best test of truth is the power of the thought to get itself accepted in the

84 Texas v. Johnson, 491 U.S. 397 (1989).

${ }_{85}$ Madu, supra note 34, at p. 506.

${ }^{86}$ R.A.V. v. City of St. Paul, 505 U.S. 377, 416 (1992).

${ }^{87}$ Martin, supra note 1, at p. 489.

${ }^{88}$ Wisconsin v. Mitchell, 508 U.S. 476 (1993) at p. 488. (attack from a young black man against a young white boy; the sentence was increase, because the court found that he had selected his victim based on race). 
competition of the market, and that truth is the only ground upon which their wishes safely can be carried out ${ }^{89}$.

Nevertheless, it is strongly contested that hate speech itself operates to undermine the free marketplace of ideas because it not only distorts the search for truth but Furthermore, it is contended that it is hypocritical when someone claims that he is for racial justice and allows people to speak against $\mathrm{it}^{90}$. But, on the other hand, once the State can deem what speech is acceptable and what is not, there is no end to what restrictions the State can impose on speech (e.g. about cruelty to animals).

This hard-line approach on hate speech referred to above is, inter alia, explained by the fact that, as Little notes, "[m]any today view such speech itself as a direct attack on the psyche of minority individuals and groups" ${ }^{\prime 1}$. However, as little further notes, the subsequent Brandenburg test, replacing prior formulations ${ }^{92}$, "[i]gnores the alternative ground affirmed in Chaplinsky: words which by their very utterance inflict injury" ${ }^{\prime \prime 3}$. In that regard, we can see that, by also failing to condemn mere abusive advocacy, the Greek anti-racist Law (Article 1(1)) seems to accord with the direction in Brandenburg ${ }^{94}$. But other countries (e.g. Germany) have adopted the above hardcore approach against expressions of racism and xenophobia. Knechtle suggests that two factors play an important role in making hate speech laws: "(1) historical accounts of ethnic, racial and religious violence, genocide, and discriminatory practices ${ }^{95}$; and

89 Abrams v. United States, 250 U.S. 616 (1919), at p. 630 (Holmes, J., dissenting). That case involved the circulation of leaflets calling for a general strike in ammunition plants to undermine the US war effort.

${ }^{90}$ See for that position, Loewy, supra note 3741, at p. 69 (with further references).

${ }^{91}$ Little, supra note 7, at 581. For the effects of hate speech, see analytically Jeremy Waldron, The Harm in Hate Speech, Cambridge, Mass.: Harvard University Press, 2012.

92 Sic Schwartz, supra note 46, at p. 236, 237-38.

${ }_{93}$ Little, supra note 7, at p. 593.

${ }^{94}$ On the other hand, the same Law bans conduct with abusive character as regards offences of public approval or denial of crimes of genocide, war crimes, and the like (Article 2(1)). However, it should be noted here that both French and Spanish Constitutional judicial authorities declared similar provisions unconstitutional, see for that Perinçek v. Switzerland, 15 October 2015, §§ 95-97, ECHR.

${ }_{95}$ Knechtle, supra note 16, at 552. Cf. also Bakircioglu, supra note 88, at p. 2 ("Germans, for instance, are naturally more sensitive about Nazi propaganda than other nations"). 
(2) jurisprudential history"96. Therefore, continues Knechtle, "Hate speech regulations are becoming increasingly prevalent in states that experience or have experienced severe racial tensions and atrocities" ${ }^{\prime \prime 7}$.

\section{B. EXPLICIT OR IMPLICIT INCITEMENT TO ACTION?}

Regardless of the aforementioned misgivings, the distinction between advocacy of belief and advocacy of actions is often difficult to assess. In particular:

\section{GROUNDS FOR EXPLICIT INCITEMENT}

As Justice Holmes noted in his Gitlow dissent, "[E]very idea is an incitement" ${ }^{98}$. "Incite to actions" means "arouse", "solicit", "urge" somebody to do something; it does not mean "prompt" somebody to adopt other's views. Therefore, acts of proselytism to racist ideology do not constitute incitement ${ }^{99}$. Moreover, the advocating speech should be unconditional; phrases like, "it is possible", "maybe", "I think that" etc., constitute, usually, only a rhetorical stimulus not a substantive motive that leads to deeds and action. Brandenburg, for instance, only talked of "possible" revenge and advocated a march on Washington some six days later ${ }^{100}$. It is suggested that Brandenburg's call did not advocate any action at all, so clearly that the Court did not even need to explore the issues of "imminence" or "likely" result ${ }^{101}$.

Accordingly, it is beyond dispute that there is advocacy of action when the incitement is immediate, definite, direct, and supported by arguments

${ }^{96}$ Knechtle, supra note 16, at p. 552.

97 Ibid.

${ }_{98}$ Gitlow v. New York, 268 U.S. 652, 673 (1925).

99 Papacharalambous, supra note 20, at p. 217.

100 Brandenburg v. Ohio, 395 U.S. 444, 446 (1969).

101 See Gilles, supra note 3, at p. 527; Healy, supra note 58, at p. 666; Redish, supra note 10, at p. 1176. See also Clay Calvert, Reconsidering Incitement, Tinker and the Heckler's Veto on College Campuses: Richard Spencer and the Charlottesville Factor, "Northwestern University Law Review Online" 2017-2018, vol. 112, pp. 109, 120 (noting that "Brandenburg couched his language in conditional terms rather than stating an immediate directive"). 
that are capable of seriously causing a person to decide to act promptly ${ }^{102}$. Of course, an elaborate salutation to the audience is not necessary; it would seem excessively formal to conclude that the advocator's failure to use a typical form of address, e.g. using the addressees' names in the vocative case, would make it any less capable of being read as an exhortation ${ }^{103}$.

\section{INDIRECT, IMPLIED OR "CAMOUFLAGED" INCITEMENT}

It is reasonably maintained that indirect or implied incitement may be punishable too ${ }^{104}$. As Professor Crump notes, " [c]amouflaged incitement may be as effective in some circumstances as its open or express counterpart" ${ }^{\prime 105}$. Hereto, two factors are important: First, the "flexibility of language, indeed of communication", and second, the admission that "the context can determine the meaning"106. That is the case, e.g., when someone's conduct as a whole (e.g. emotionally charged words, words of fire etc.) is likely to cause for the average person intense, not just normal, emotions of hate ${ }^{107}$. The Canadian Supreme Court also demands for the constitutionality of hate speech limitations that they prohibit conducts rising at least to the level of "ardent and extreme feelings"108. Professor Papacharalambous adopts the "implied incitement" theory and insightfully cites the Ruggiu/Radio Mille Collines and Akayesu decisions of the International Criminal Tribunal for Rwanda (ICTR), which held that the word 'insects' attributed to Tutsis constituted punishable incitement ${ }^{109}$.

As concerns the Brandenburg test, it seems that it allows the government to prosecute speech only if the speech explicitly incites illegal action ${ }^{110}$. On

102 Cf., in Greece, Criminal Court of Rethimnon No 2383/2015, PoinChr 2017, 450, at para. 67.

103 Sic Crump, supra note 11, at 15-16 n. 95.

104 Sic, in Greece, Criminal Court of Rethimnon No 2383/2015, PoinChr 2017, 450, at para. 70 .

${ }^{105}$ Crump, supra note 11, at p. 9.

106 Ibid., at 18.

107 See also Criminal Court of Rethimnon No 2383/2015, PoinChr 2017, 450, at para. 70.

108 Whatcott v. Saskatchewan Human Rights Tribunal, [2013] 1 S.C.R. 467 (Can.), at. para. 89, 111.

109 Papacharalambous, supra note 20, at p. 213, 218.

110 Gey, supra note 30, at 977. 
the other hand, it is strongly contested that its principles do not exclude prima facie implicit incitement. According to Professor Crump,

[i]f the Klan leader were to turn to the white-robed minion with the shortest fuse right after his "revengeance" remark and say, "Duke, what are you going to do about that?" perhaps the case becomes different. In this situation, the Klan leader's remarks arguably are "directed to ... producing imminent lawless action" by the short-fused "Duke," even though part of the communication is derived from the context and even though the message is implied ${ }^{111}$.

For that reason, Crump summarizes the factors that should be weighed in deciding the question of incitement:

(1) the express words or symbols uttered; (2) the pattern of the utterance, including any parts of it that the speaker and the audience could be expected to understand in a sense different from the ordinary; (3) the context, including the medium, the audience, and the surrounding communications; (4) the predictability and anticipated seriousness of unlawful results, and whether they actually occurred; (5) the extent of the speaker's knowledge or reckless disregard of the likelihood of violent results; (6) the availability of alternative means of expressing a similar message, without encouragement of violence; (7) the inclusion of disclaimers; and (8) the existence or nonexistence of serious literary, artistic, political, or scientific value ${ }^{112}$.

However, there is no presumption that every act of hate speech, prima facie, incites to violence or other hateful acts ${ }^{113}$. Such a presumption in laws purporting to limit hate speech would render the relevant provision unconstitutional. In a similar case regarding the prohibition of cross burning, the US Supreme Court held unconstitutional a clause that made cross burning prima facie evidence of intent to intimidate ${ }^{114}$. According to Justice O'Connor, the presumption meant that the State could "[a]rrest,

111 Crump, supra note 11, at p. 14.

112 Ibid. at 51 et seq.

113 But see Knechtle, supra note 16, at p. 546 (arguing that "[T]o ignore or deny the relationship between hate speech and the threat or incitement to violence is to not know history, including recent history").

114 Virginia v. Black, 538 U.S. 343, 365 (2003). 
prosecute and convict a person solely on the fact of cross burning itself", which would "[c]reate an unacceptable risk of the suppression of ideas"115.

The indirect or implied incitement theory can be illustrated in the following paradigm: An archpriest says in his preaching the following words concerning homosexuality: "Homosexuality is a sin; homosexuals will burn in the eternal inferno. Spit on them whenever you see them". Is this advocacy an advocacy of ethics or the priest actually urges his fold to spit on homosexuals? If it is advocacy of belief, would it be converted into advocacy of action if the archpriest were to say, in a very enthusiastic or impassioned way, to an excited or furious audience: "Spit on homosexuals"? In Hess, the U.S. Supreme Court, employing the Brandenburg standards, held that Hess's statement was simply an emotional exclamation rather than a potentially effective exhortation to action directed specifically at a particular group of persons ${ }^{116}$. Moreover, it should be noted that the archpriest's speech is uttered by a man with authority and influence over the people to whom he is addressed. Hereto, Lynd aptly pinpoints possible variables for the above conversion, i.e. the intent inferred from the excited tone of voice, the crowd's actual reaction, and the crowd's rationally predictable reaction, regardless of how it actually reacted ${ }^{117}$.

On the other hand, one should ask oneself if the abovementioned speech of the archpriest is a mere abstract teaching or a preparation of a group for violent action ${ }^{118}$. The U.S. Supreme Court, in a case about communist threats, held that:

[t] he mere abstract teaching of Communist theory, including the teaching of the moral propriety or even moral necessity for a resort to force and violence, is not the same as preparing a group for violent action and steeling it to such action ${ }^{119}$.

115 Ibid.

116 Hess v. Indiana, 414 U.S. 105, 107-108 (1973). In that case the defendant was convicted of disorderly conduct when he shouted "We'll take the fucking street later" to a group of protestors.

${ }_{117}$ Lynd, supra note 2, at p. 156.

118 Cf. Brandenburg v. Ohio, 395 U.S. 444, 447-48 (1969).

119 Noto v. United States 367 U.S. 290, 297-98 (1961). 
In this regard, in a case concerning the distribution of leaflets against homosexuality, the ECHR put emphasis on the wording of the leaflets (e.g., 'homosexuality is a deviant sexual proclivity [with] a morally destructive effect on the substance of society') and opined that "[a]lthough these statements did not directly recommend individuals to commit hateful acts, they are serious and prejudicial allegations"120. Worse still, and that is most important, the offenders had distributed the leaflets in a school, leaving them in or on the pupils' lockers, thereby imposing them on the pupils. This conduct should be considered as an incitement, whether or not implied, to hateful acts.

Furthermore, in a Greek legal case regarding inflammatory speech against Israelis, a local district attorney indicted an alleged Muslim religious leader under Greek anti-racist Law No 927/1979 (Article 1(1)) ${ }^{121}$ and charged him with advocating actions leading to racial hate and violence. His words on Facebook, however, didn't seem to constitute prima facie incitement to lawless action. He expressed over the internet his concern about the "fire" in Israel, portrayed all Israelis as a monster that feeds on blood, and alleged that Israelis drool over catastrophes in uncountable countries. But he continued his statement by expressing his disappointment because no one in Greece wants to take measures against them. May this last utterance actually be regarded as a punishable incitement to acts of discrimination, hate, or violence? It is worth noting here that the district attorney took into consideration the advocate's capacity as a religious leader who exerts influence over his "online" audience.

On the other hand, the Greek Supreme Court judged that the mere utterance of a scientific opinion or critique, if unpleasant or critical of members of a race or nationality, does not constitute incitement to actions $^{122}$. In the relevant case concerning an anti-Semitic book, the Court acquitted the writer on the basis that, inter alia, the latter refers in his book only to specific incidents and merely evaluates negatively the behaviour of specific individuals according to his personal belief. Indicatively, the Court judged that the phrase in the book, "[t]he White Race does not

120 Vejdeland and Others v. Sweden, 9 February 2012, § 54, ECHR.

${ }^{121}$ For the factual background of the case, see Greek Supreme Court (Council) No 1338/2017 (although judging procedural issues only).

122 Greek Supreme Court (Plenary Session) No 3/2010. 
want Semites in Europe since it is in its best interest genetically", does not constitute incitement to actions. Mallios criticizes the grounds of the above judgment and expresses the view that many of the writer's expressions, considered per se or in context, provoke and insult the Jewish race and each of its members individually ${ }^{123}$. But, it should be noted that mere fighting, hate, or insulting words against a race do not constitute an offence under Greek anti-racist Law anymore ${ }^{124}$, unless, of course, someone follows the "indirect or implied incitement" doctrine according to which the extremely provocative utterance of ideas may cause intense emotions of hate likely resulting in prohibited acts against targets.

\section{Public Order Policy as an Underlying PRINCIPLE}

Both the Brandenburg Test and the Greek anti-racist Law seek to regulate inciting hate speech on grounds relating to the existence of a threat to public order.

\section{A. The Reservations Adopted by the Greek Anti-racist LAW AND THEIR REFLECTION IN BRANDENBURG'S MIRROR}

In order for hate speech (e.g., against immigrants, Muslims, Roma etc.) to be punishable by the Greek anti-racist Law, it is necessary, inter alia (intentional incitement to actions, public articulation of speech ${ }^{125}$ directed

${ }^{123}$ Vaggelis Mallios, Freedom of Expression and Racist Speech, Note on Greek Supreme Court (plenary session) no 3/2010 (in Greek), DiMEE 2010, 385, under A.

${ }^{124}$ But see Jersild v. Denmark, 23 September 1994, § 35, ECHR (noting that concrete expressions constituting hate speech, which may be insulting to particular individuals or groups, are not protected by Article 10 of the Convention of Human Rights). The same court, however, demystifies elsewhere the view that "the mere fact of defending sharia, without calling for violence to establish it, cannot be regarded as 'hate speech'”, Gündüz v. Turkey, 4 December 2003, § 51, ECHR.

125 Yet, scholars have questioned whether Brandenburg applies only to public speech (such as town-square advocacy) or also to secret meetings (see hereto Gilles, supra note 3 , at 529, and the references cited therein). 
against socially vulnerable groups of individuals), for the speaker's words to endanger public order or to pose a threat to the life, liberty, or bodily integrity of the offended persons (Article 1(1)).

It is worth noting here that the two aforementioned reservations are laid down potentially in the European Council Framework Decision 2008/913/JHA since under its Article 1(2), “[M]ember States may choose to punish only conduct which is either carried out in a manner likely to disturb public order or which is threatening, abusive, or insulting". Greece partly transposed both those reservations into national law ${ }^{126}$. In that way, the Greek legislature is intended to be balanced between equality and freedom of speech, excluding expressions inappropriate to generate sufficient and massive victimization of targets from its scope ${ }^{127}$.

Respectively, Brandenburg relates to the first reservation. In particular, the Brandenburg test constitutes an exemption to full First Amendment protection primarily for reasons of public order since, as Martin notes, " $[t]$ he concern is that the speech will provoke or elicit a response that will be violent or criminal" 128 . In other words, the underlying concern in Brandenburg is about the reaction of the target audience which may result in violence disturbing public order ${ }^{129}$. Therefore, the public order proviso is implicit in Brandenburg, while it is explicitly expressed in the Greek anti-racist Law. This may be attributed to the fact that the Brandenburg test primarily relates to lawless actions of violence, the main and selfevident enemy of social peace, while the Greek anti-racist Law proscribes also incitement to actions or activities likely resulting in discrimination or hatred.

As regards the second reservation in connection with the status quo in the United States, it is stated that speech may also be restricted there based on its content if it falls within the narrow class of "true threats"

${ }^{126}$ See also Kaiafa-Gbandi, supra note 45, at p. 104 (with specific reservations criticizing the Greek legislator's initiative).

${ }^{127}$ Opposed to that Kaiafa-Gbandi, supra note 45, at p. 105.

${ }^{128}$ Martin, supra note 1, at p. 485; Gey, supra note 30, at p. 1047 (arguing that the Brandenburg paradigm "by its very terms protects the government's interest in preserving order".

${ }^{129}$ Martin, supra note 1, at p. 494. Cf. also Knechtle, supra note 16, at p. 548 (noting that "[g]overnments around the world have enacted hate speech codes that address the harm of violence, or the potential for violence"). 
of violence ${ }^{130}$. The "true threats" doctrine refers to the State's power to punish a speaker who "directs a threat to a person or group with the intent of placing the victim in fear of bodily harm or death"131. This category extends to threatening speech that creates fear in the target even if expressed without intent to actually cause harm ${ }^{132}$. Therefore, this test should be combined with the Brandenburg test ${ }^{133}$.

In sum, the Greek anti-racist Law (Article 1(1)) adopts two criteria, danger to the public order on the one hand (analogous to Brandenburg's "imminence" test ${ }^{134}$ ), and threat to the life, liberty, or bodily integrity of individuals or groups of individuals on the other (analogous to the "true threats" doctrine ${ }^{135}$ ).

\section{B. Defining the Endangerment of Public Order}

It is clear from the above that the underlying policy both in American and Greek law is to maintain public order. Therefore, the Brandenburg logic unequivocally can be detected in the Greek anti-racist Law. Yet, Professor Martin expresses his objections to that policy:

${ }^{130}$ U.S. Periodic Report for CERD (2013) at para. 51. But, many of the opinions raising the true threats issue involve speech of a political nature, sic Gey, supra note 30, at p. 1005.

131 Virginia v. Black, 538 U.S. 343, 359-60 (2003). In that case, the Court held that " $[\mathrm{t}]$ he act of burning a cross" during a Klan meeting did not constitute a true threat in the absence of proof of an intent to intimidate (ibid. at 348, 365). For the "true threats" doctrine, see also Watts v. United States, 394 U.S. 705 (1969), at 707 (holding that war protestor's joking comment during a political rally that he would shoot LBJ was a "political hyperbole," and not a "true" threat); Paul T. Crane, True Threats" and the Issue of Intent, "Virginia Law Review" 2006, vol. 92, p. 1225; Gilles, supra note 3, at 531-32. For a relevant draft hate speech statute, see Little, supra note 7, at p. 579.

132 Sic Little, supra note 7, at p. 585, 598.

133 See also Knechtle, supra note 16, at p. 543.

${ }^{134}$ Cf. also the second branch of Chaplinsky's Test referring to words that "[t]end to incite an immediate breach of the peace", Chaplinsky v. New Hampshire, 315 U.S. 568 (1942), at p. 572 (though applying to face-to-face speech). See also Little, supra note 7, at p. 597-98.

135 Yet, the Greek Law's "threat prerequisite" refers to inciting racist speech, whereas for, as regards to "true threats"”, , the speaker himself threatens to do violence to a particular individual. For this subtle distinction between Brandenburg and Black, see Gilles, supra note 3 , at p. 532, n. 89. 
The concern is not imminent violence or disturbance of the peace, but the serious harm that hate speech can cause to not only the targets of hatred and the victims of the resulting discrimination and persecution, but to the democratic values and the rule of law itself. It is ultimately a concern for the protection of the constitutionally grounded right to equal protection and equal benefit of the law. This provides a powerful constitutionally based explanation for the object and purpose of hate speech laws ${ }^{136}$.

In particular, the public order relates to a peaceful and normal social coexistence. Compelling interests require that members of groups that have been historically subjected to discrimination shall have the right to live in peace where they wish ${ }^{137}$. Furthermore, the disturbance of public order means, inter alia, that the controversial inciting speech should be viewed in a state showing an objective likelihood of (imminent) lawless action as a result of the speech ${ }^{138}$. In other words, the advocacy must purport to bring about, rather than merely try to stir up, unlawful conduct ${ }^{139}$; it is only then that the inciter may endanger public order. The Brandenburg standard itself requires a likelihood of imminent harm. Lowey insightfully illustrates the above position with the following dialogue:

Hans: Precisely my point. You allow a speaker to add insult to the injury that African Americans were suffering at that time in your nation's history, and you let minorities know that it is okay for bigots to spew their hate. What kind of message of inclusiveness is that?

136 Martin, supra note 1, at p. 521-22.

137 See also R.A.V. v. City of St Paul, 505 U.S. 377 (1992) at 395. Cf. also Little, supra note 7, at p. 595 ("that is, without cross-burnings on their front lawn").).

${ }^{138}$ Cf. also Hutchin v. State, 290 So. 2d 35, 38 (Fla. 1974) (Ervin, J., concurring); Criminal Court of Rethimnon No 2383/2015, PoinChr 2017, 450, at para. 70 (according to which "[t]hose emotions [of dislike, repugnance, gloat, vengeance, and extreme hostility] are objectively capable of urging the individuals to adopt lawless action").

139 Richard A. Posner, The Learned Hand Biography and the Question of Judicial Greatness, "Yale Law Journal", 1994, vol. 104, pp. 511, 516. See also Crump, supra note 11, at 50 ("[S]peech that 'stirs up' or 'sets in motion' an ultimate chain of events generally is protected, even if the last, most remote event happens to be unlawful"). 
John: You're missing the whole point. You can say anything you want, but you can't do anything you want. Clarence Brandenburg can express his desire for the deportation of groups that he finds undesirable. But the government cannot implement his views. Thus, in the highly unlikely event that Brandenburg was able to persuade Congress to enact his political agenda, the Supreme Court would declare it unconstitutional. Hence, there is no possibility that Brandenburg's views would ever become the law of the land ${ }^{140}$.

Calvert concurs with the above arguments and emphasizes the fact that the inflammatory speech of Brandenburg was addressed to a handful of Klansmen and a reporter, further noting that "these words were not likely to produce the type of imminent lawless action that the Brandenburg test demands"141. According to Malloy \& Krotoszynski, "[s]peech can be regulated only when the generalized threats and calls to action are likely to bring about an immediate breach of the peace; in other words, to persuade listeners to act immediately and unlawfully"142. Therefore, vague threats of violence are constitutionally protected.

Yet, it is strongly contested that hate speech itself may disturb public order, regardless of whether it incites to lawless action; this is because hate speech inspires fear and self-resignation ${ }^{143}$. Following a similar approach, professor Kaiafa-Gbandi supports the view that targets are already victimized by advocators uttering mere hate speech due to the latter's public denial of human value ${ }^{144}$. However, it cannot be accepted as "carved in stone" truth that the public order is endangered by mere inflammatory propaganda. Where appropriate, i.e. in States sorely tried by events that have come to define their history (e.g. Nazi Germany), racist propaganda may be perceived to endanger public order.

In the Greek legal context, the aforementioned likely lawless action must disturb the "core areas of both the functioning of the State and the legal order"145. This happens when even a vigilant police force may

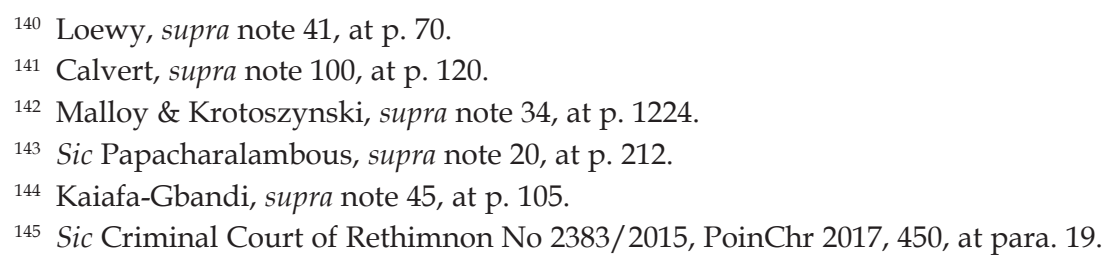


face difficulties in keeping socially vulnerable individuals from being attacked or excluded; or when the hate words may touch off a riot ${ }^{146}$. For example, it should be remembered that that "it was hateful speech and unrestrained freedom of expression that generated the massive and hostile public gatherings in Charlottesville [in August 2017], and a young woman was killed as a direct result"147.

Attention should be drawn, at this point, to the risk of retaliation due to inflammatory racist speech. This factor should also be taken into consideration when estimating the dangers of the disturbance of public order. In that context, Knechtle quotes Kahane's paradigm in Israel. Rabbi Kahane was uttering anti-Arab words so that his ideas were not warmly received by Arab citizens and the police were forced to quell the resulting confrontations ${ }^{148}$. But, for the hate speech to be punishable, it must also incite to actions of discrimination, hate, or violence and not just be provocative towards targets. As Madu cogently comments on the phenomenon of depicting the Prophet Muhammad, "[ $t$ ]hose depicting the Prophet Muhammad do so peacefully and do not commit violent acts themselves; instead they are attacked by radicalized gunmen responding to their depiction"149; thus, Madu concludes that "[t]he Brandenburg test as it exists today is not applicable to these depictions"150.

Moreover, even before Brandenburg, American case law implemented the doctrine of "clear and present danger", which has similarities to the Greek Law's criterion of "danger to the public order". In fact, the "clear and present danger" doctrine is considered the predecessor to the Brandenburg test ${ }^{151}$. Justice Holmes had emphasized that "[I]t is only the present danger of immediate evil or an intent to bring it about that warrants Congress in setting a limit to the expression of opinion" ${ }^{\prime 152}$, as well as that it is crucial for a jurist to search "whether the words used are used in such circumstances

${ }^{146}$ Cf. hereto also R.A.V. v. City of St Paul, 505 U.S. 377 (1992) at 416 (Justice Stevens).

147 Little, supra note 7, at p. 581 (referring to "vitriolic white supremacist and Naziinspired ethnic attacks and violence").

148 Knechtle, supra note 16, at p. 549.

149 Madu, supra note 34, at p. 511.

150 Ibid.

151 Montgomery, supra note 9, at p. 144.

152 Abrams v. United States, 250 U.S. 616 (1919) at p. 628. 
and are of such a nature as to create a clear and present danger"153. According to Professor Schwartz, the clear and present danger test was based on the analogy of the law of criminal attempts:

Just as a criminal attempt must come sufficiently near completion to be of public concern, so there must be an actual danger that speech will bring about an unlawful act before it can be restrained. In both cases, the question how near to the unlawful act itself the attempt or speech must come is a question of degree to be determined upon the special facts of each case ${ }^{154}$.

In the same vein, a Greek Criminal Court refers specifically to the adequacy of the conduct in question to cause direct and imminent danger to peaceful and normal social harmony ${ }^{155}$. In other words, the danger must be specific and imminent; i.e., the crucial words must create a specific threat of immediate violence or hateful acts and not just have a tendency to lead to them in the future ${ }^{156}$. As regards the Greek anti-racist Law, Professor Papacharalambous acknowledges the 'specific danger' requirement, however, he seems reluctant when he notes that the above solution "[i]s extremely favourable to the offender"157. But Chouliaras notes that the ECHR also demands that hate speech must generate a direct and imminent danger ${ }^{158}$.

Brandenburg makes imminence a key component too ${ }^{159}$. According to Redish, the Brandenburg test demands in particular "temporal imminence ${ }^{\prime 160}$. Indeed, the imminence-factor was reaffirmed by the Hess

153 Schenck v. United States, 249 U.S. 47 (1919) at p. 52. (distribution of leaflets urging the public to disobey the draft during World War I).

154 Schwartz, supra note 46, at p. 217.

155 Criminal Court of Rethimnon No 2383/2015, PoinChr 2017, 450, at para. 34.

156 Gooding v. Wilson, 405 U.S. 518 (1972). On the contrary, see for the tendency-test Whited v. State, 256 Ind. 386 (1971) at p. 391. In the Greek legal context, Chouliaras excludes from the scope of the Greek anti-racist Law cases relating to danger in the "distant and cloudy future", Chouliaras, supra note 16, at p. 1234.

157 Papacharalambous, supra note 20, at 214.

158 Chouliaras, supra note 16, at p. 1231 (citing Erbakan v. Turkey, 6 July 2006, ECHR).

159 Sic Gilles, supra note 3, at p. 524. See also Smolla, supra note 57, at p. 22.

160 Redish, supra note 10, at 1176. See also Malloy \& Krotoszynski, supra note 34, at 1193; Schwartz, supra note 46, at p. 239 (noting that 'incitement" implies immediacy); Lucas A. Powe, Jr., Brandenburg: Then and Now, "Texas Tech Law Review", Volume 44 2011-2012, p. 69-71 (2011-2012) (“[v]iolence must happen now”). 
Court ${ }^{161}$ after which it is broadly reasoned that even a delay of mere hours is insufficient to meet the imminence requirement ${ }^{162}$. Gey also notes that, "[A]ny lapse in time between speech and action frees the speaker from the legal consequences of his or her advocacy"163. However, Brandenburg's opinion lacks any definition of "imminence"164. In this regard, Professor Crump expresses a different view, noting that "[i]t is imminence in the sense of the predictability of the result that is properly understood as the concern of Brandenburg", as well as that "[I]f imminence were interpreted instead to mean simply the immediacy in time of the result, the Brandenburg test would not make sense" 165 .

Yet, as is widely acknowledged, the clear and present danger test proved remarkably ineffective at protecting speakers since it was used to suppress the speech of communists, socialists, and other radicals more often than it was used to protect them ${ }^{166}$. Professor Crump cogently notes that the clear and present danger test emphasized on outrageously harmful utterance, but it ignored the communicative value of the latter, so that "[T]his transmutation of the clear and present danger test into a 'reasonably probable effect' standard aggravated the already unacceptable risk that speakers might be convicted for general criticisms of government rather than for incitement of unlawful conduct"167.

The abovementioned doctrine was distilled by the Brandenburg Court, the latter requiring both incitement to action and a clear and present (imminent) danger before speech may be forbidden or proscribed ${ }^{168}$.

${ }^{161}$ Hess v. Indiana 414 U.S. 105 (1973).

162 See hereto Gilles, supra note 3, at 524 (citing other commentators); Rohr, supra note 53, at 12. High critical of the above reading is Crump, supra note 11, at p. 18.

163 Gey, supra note 30, at p. 978.

${ }^{164}$ Gilles, supra note 3, at p. 528.

165 Crump, supra note 11, p. at 59-60 (citing Professor Greenawalt's example of a local racist who begins in June with repeated messages urging each white person in the community to identify an African-American and make plans to kill that individual on July 4 to celebrate Independence Day).

166 See Gilles, supra note 3, at p. 520-21; Lidsky, supra note 5, at p. 1026.

167 Crump, supra note 11 , at p. 7, 8 .

${ }^{168}$ Lynd, supra note 2, at p. 159; Gunther, supra note 22, at 722; Gilles, supra note 3, at p. 521. See also, previously, Bond v. Floyd, 385 U.S. 116 (1966) (holding remarks supporting draft resisters were protected because they did not include express advocacy of illegal action). 
A few years later, the same Court affirmed the Brandenburg principles ${ }^{169}$. We should remember here that the Greek anti-racist Law also requires incitement to reproachable acts or activities in a manner which endangers public order or poses a threat to the life, liberty or bodily integrity of socially vulnerable individuals ${ }^{170}$. Therefore, nowadays, advocacy of action at some uncertain time in the future seems prima facie to be constitutionally protected ${ }^{171}$. As Crump put it, "A speaker can be held responsible for his own utterances, but not for the countless possibilities that violence may ensue when the words are interpreted by unknown persons at an indefinite time in the future"172.

\section{Establishing the Endangerment of Public Order}

Hate speech inciting to an unlawful action will be be punishable if one can find evidence of imperilment of public order in the circumstances and the nature of the words used.The Greek anti-racist Law does not punish all expressions of racism or xenophobia, but it purports to combat particularly serious and coercive (therefore dangerous) forms and expressions of racism and xenophobia by means of the criminal law. By way of illustration, let us imagine the following working hypothesis: Enraged by an Islamist's suicide attack, a journalist of a politically radical local newspaper writes an article where he expresses the view that the Islamists living in his town are would-be terrorists and citizens of that town must be very "cautious" when interacting with them, especially when they see frowning, nervous, or turbulent faces ${ }^{173}$. Likely, this speech is constitutionally unprotected because it seems to incite the shorttempered (due to the recent suicide attack) readers of the newspaper to

169 Hess v. Indiana 414 U.S. 105 (1973). So did the lower courts (see Lynd, supra note 2, at p. 163).

${ }^{170}$ In Greece, it is contended that the mere expression of ideas contrary to the prevailing social notions shall not put the public order in danger (see hereto Criminal Court of Rethimnon No 2383/2015, PoinChr 2017, p. 450, at para. 18).

171 See also Lynd, supra note 2, p. 170.

172 Crump, supra note 11, p. 13.

${ }^{173}$ For a brief summation of the phenomenon of Islamophobia, see Madu, supra note 34 , at p. 491 et seq. 
act badly against Islamists in the vicinity of the journalist, in a manner that provokes imminent lawless action and endangers public order. More specifically:

\section{Surrounding Circumstances}

The same words are evaluated differently depending on the circumstances in which they are used. These circumstances may be distinguished as follows:

\section{a) HISTORICAL OR SOCIAL BACKGROUND}

Justice Holmes expressed the view that many things that might be said in time of peace will not be endured in time of war ${ }^{174}$. In our days, particularly after 9/11, the "war on terror" has been at the forefront of attention for much of that time. Kantor notes that "[i]t remains to be seen whether Brandenburg will be able to guard free speech during this new period of national insecurity"175. Equally, Judge Posner posited that " $[w]$ hen the country feels very safe the Justices of the Supreme Court can without paying a large political cost plume themselves on their fearless devotion to freedom of speech"176. In the above context, Professor Gilles calls Brandenburg a "too easy" case because it was not decided in a time of national fear ${ }^{177}$. In a case about inflammatory words uttered in an interview published in a major national daily newspaper by a former mayor of Diyarbakir, the most important city in south-east Turkey, the ECHR rightly observes that,

174 Schenck v. United States, 249 U.S. 47 (1919), at p. 52 (Holmes, J., referring to a Socialist pamphlet that opposed American entry into World War I).

175 Elisa Kantor, Note, New Threats, Old Problems: Adhering to Brandenburg's Imminence Requirement in Terrorism Prosecutions, "The George Washington Law Review" 2008, vol. 76, pp. 752, 765. But see Montgomery, supra note 9, at p. 159 (noting that "[w]ith so many years passing without any more attacks, and with no demonstrable evidence of a growing terrorist threat within our borders, it is not a stretch to argue that the threat is largely contained").

176 Richard A. Posner, Pragmatism Versus Purposivism in First Amendment Analysis, "Stanford Law Review", 2002, vol. 54, pp. 737, 741.

177 Gilles, supra note 3, at p. 528. 
The statement cannot, however, be looked at in isolation. It had a special significance in the circumstances of the case, as the applicant must have realized. As the Court noted earlier [...] the interview coincided with murderous attacks carried out by the PKK on civilians in south-east Turkey, where there was extreme tension at the material time $[\ldots]$ the support given to the PKK $[\ldots]$ had to be regarded as likely to exacerbate an already explosive situation in that region. The Court accordingly considers that the penalty imposed on the applicant could reasonably be regarded as answering a "pressing social need" and that the reasons adduced by the national authorities are "relevant and sufficient"

Respectively, it seems that a democratic society becomes less tolerant when it feels threatened by increasing instances of racism and xenophobia. In those circumstances, even moderately inciting racist speech may be regarded as endangering public order.

\section{b) The Prestige of the Speaker}

As Justice Ervin insightfully noted, "[a] speaker's cry for warfare in the streets or to burn city hall which evokes only a response of laughter from his audience would not intrinsically amount to a criminal utterance"179. In Brandenburg, the record also revealed almost no evidence of clear and present danger. As Tribe notes, "Brandenburg protects the harmless inciter"180. Gilles, commenting on Brandenburg, specifically mentions that "[n]obody can suppose that a silly hateful speech by an unknown man would present any immediate danger to the President, Congress, or the Supreme Court"181.

On the other hand, a Greek court martial emphasized that no one questions the patriotism of those who are in Special Forces in the army, but, subsequently, held that the abovementioned admission cannot provide immunity to the latter since their actions, in general, have a multiplier impact on the society in their capacity as members of the

178 Zana v. Turkey, 25 November 1997, §§ 59-61, ECHR.

179 See Hutchin v. State, 290 So. 2d 35, 38 (Fla. 1974) (Ervin, J., concurring).

${ }^{180}$ Laurence H. Tribe, American Constitutional Law, Second Edition, New York: Foundation Press, 1998, p. 849.

181 Gilles, supra note 3, at p. 519. 
security forces ${ }^{182}$. It is worth noting here that the issue in the relevant dispute related to obscene and provocative slogans uttered at a military parade against third-country nationals.

\section{c) Public Dialogue and Nature of Audience}

Hate speech loses its impact and inevitably its capacity to disturb social peace when it is uttered in the course of a pluralistic debate. The latter happens, as the ECHR noted, whenever the inflammatory views are discussed in the public arena and are counterbalanced by the opposite partisans ${ }^{183}$.

On the other hand, hate speech threatens to become dangerous when it addresses crowds in public assemblies ${ }^{184}$ or crowds at an impressionable and sensitive age $\mathrm{e}^{185}$.

\section{d) Means of Utterance of Speech}

For hate speech to incite likely imminent action (or endanger public order), the degree of its influence must be evaluated in the light of the means through which it is uttered. The ECHR notes that " $t]$ he audiovisual media have often a much more immediate and powerful effect than the print media" because, "[T]he audiovisual media have means of conveying through images meanings which the print media are not able to impart" ${ }^{\prime 186}$. In this context, noteworthy also are the U.N. reports on the Rwandan genocide of 1994. As Bakircioglu notes,

\footnotetext{
${ }^{182}$ Court Martial of Piraeus No 588/2011 (judging though on the base of pre-existing law).

183 Gündüz v. Turkey, 4 December 2003, § 51, ECHR.

${ }^{184}$ Cf. Mallios, supra note 122, under C.

185 Vejdeland and Others v. Sweden, 9 February 2012, § 56, ECHR (referring to leaflets against homosexuality left in the lockers of pupils who had no chance to decline to accept them).

186 Jersild v. Danemark, 23 September 1994, § 31, ECHR. For policing online speech through ISPs, see analytically Montgomery, supra note 9, at p. 168 et seq. On the other hand, Germany will subject persons to criminal prosecution for providing a hate speech site accessible to Germans, sic Knechtle, supra note 16, at p. 540. Finally, for preventive intervention instruments against racial discrimination used by independent administrative authorities, see Antoine Maniatis, Les autorités indépendantes et les droits de l'homme, “Annuaire International des Droits de l'Homme" IV/2009, p. 505, 518-21.
} 
The then U.N. special rapporteur vividly illustrated how radio transmissions played a central role in inciting ethnic hatred and mass murder: "[ $t]$ he generally illiterate Rwandese rural population listens very attentively to broadcasts in Kinyarwanda; they hold their radio sets in one hand and their machetes in the other, ready to go into action"187.

On the contrary, as regards hate speech in books, Mallios pertinently expresses the view that " $[\mathrm{b}]$ ooks are primarily addressed to persons who are interested in buying them and, therefore, can hardly be considered unaware of the writer's extremist views or the violence radiating from his style"188. In a case about inflammatory speech in poems, the ECHR acquitted the poet, observing that,

[t] he applicant is a private individual who expressed his views through poetry - which by definition is addressed to a very small audience - rather than through the mass media, a fact which limited their potential impact on "national security", "[public] order" and "territorial integrity" to a substantial degree. Thus, even though some of the passages from the poems seem very aggressive in tone and to call for the use of violence, the Court considers that the fact that they were artistic in nature and of limited impact made them less a call to an uprising than an expression of deep distress in the face of a difficult political situation ${ }^{189}$.

\section{NATURe ANd MEANing of THE Words Used}

An examination of the words uttered is necessary to determine if the hate speech could be proscribed. To that effect, one should also take into serious consideration whether the words at issue spawned violence or other hateful acts in the past ${ }^{190}$. In that context, words uttered in verbal decency, even if incorporating racist speech, would typically fall outside the scope of the Greek anti-racist Law ${ }^{191}$; especially when those provocative views are already known and have been discussed in the public arena ${ }^{192}$.

\footnotetext{
187 Bakircioglu, supra note 88, at p. 6.

${ }_{188}$ Mallios, supra note 122, under C.

189 Karataş v. Turkey, 8 July 1999, § 52, ECHR.

190 See also Calvert, supra note 100, at p. 121.

191 Anthopoulos, supra note 16, at p. 45-46.

192 Cf. Gündüz v. Turkey, 4 December 2003, § 51, ECHR.
} 
The Greek Supreme Court, in a case regarding an anti-Semitic book, took into consideration the fact that the writer's inflammatory words were logically and conceptually included in the denunciatory vein of the latter's book purporting to evaluate, criticize, and interpret the historical events as well as the persons connected to them ${ }^{193}$. According to the Court's judgment, the writer demanded emphatically the punishment of Jews not on the base of racial or national origin, but as a result of their acts of violence against the patriarch of Jerusalem and the holy symbols of Christianity. Furthermore, the Court judged that the writer did not incite his readers to lawless action and therefore he did not endanger the public order. The court reached its conclusion by relying upon the phrase, "[w]henever someone detects Jewish interference, he should prevent it through denunciation and then through other means". In the court's opinion, the phrasal priority in the word "denunciation" means that the writer suggests that, in order for Jewish Zionism to be confronted, lawful procedures should be followed.

This authority also seems to be compatible with the imminence requirement of the Brandenburg test. As Malloy \& Krotoszynski argue, "[B]ecause instructional books, songs, and movies generally require time for an individual to digest, such materials generally will not meet Brandenburg's imminence requirement" ${ }^{\prime 194}$.

In addition, great weight should be attached to the means of expression. In a case concerning inflammatory speech against Turkish secularism and democracy, the ECHR pointed out that " $\mathrm{t}]$ he applicant's statements were made orally during a live television broadcast, so that he had no possibility of reformulating, refining or retracting them before they were made public" ${ }^{195}$.

\section{Weighting betWeEn "Advocated EVIL" AND "MEASURE OF PROBABILITY"?}

In order for a speech \{calling?\} for lawless action to be curtailed, one should take into account both the gravity of the advocated evil and

\footnotetext{
193 Greek Supreme Court (Plenary Session) No 3/2010.

${ }^{194}$ Malloy \& Krotoszynski, supra note 34, at p. 1169.

195 Gündüz v. Turkey, 4 December 2003, § 49, ECHR.
} 
the probability (or improbability) of the latter ${ }^{196}$. This balancing test is attributed to Judge Hand, who rephrased the Holmes test on 'clear and present danger': "[I]n each case [courts] must ask whether the gravity of the 'evil,' discounted by its improbability, justifies such invasion of free speech as is necessary to avoid the danger"197. In other words, "evil" and "contingency" interact with each other like "communicating vessels". The probability of the advocated evil occurring at some indefinite future time may be low, but if the gravity of the danger is great, then the speech may be curtailed ${ }^{198}$. In this context, the speech may be curtailed more easily when the offender screams, for example, that Muslims should be massacred than when he propagates hateful acts such as intimidation, abusive verbal attacks, cursing, bullying etc.

The "communicating vessels" theory is compatible with the Greek legal system where danger to the public order is of vital importance (not primarily the imminence-factor). On the other hand, the above formulation is said to prejudice the "imminence" test in Brandenburg ${ }^{199}$. Justice Brandeis had reasoned that, "[F]ear of serious injury alone cannot justify suppression of free speech and assembly"200. Yet, it may be contested that the "communicating vessels" approach, though replaced by the Brandenburg standards, does not prejudice the "imminence" factor since it balances the latter with the gravity of the advocated evil. As Powe aptly notes, "[T]he greater the harm, the longer it is imminent" 201. Of course, extreme remoteness should not render the speech punishable irrespective of the gravity of the advocated evil.

Besides, the aforementioned approach should be connected with the incitement-factor. As Gunther notes, "Under Brandenburg, probability of harm is no longer the central criterion for speech limitations. The inciting

196 See hereto Dennis v. United States 341 U.S. 494, 510 (1951) (Vinson, C.J.). Dubious about this approach, though, Crump, supra note 11, at p. 10.

197 United States v. Dennis, 183 F2d 201, 207 (2d Cir 1950). For an analytical review, see Schwartz, supra note 46 , at 231 et seq.

${ }^{198}$ Lynd, supra note 2, at 155 (citing Dennis v. United States 341 U.S. 494 (1951), and wondering: "What could be graver than the overthrow of the government?"). See also Healy, supra note 58, at p. 681, 718-22.

199 Montgomery, supra note 9, at p. 152.

${ }^{200}$ Whitney v. California, 274 U.S. 357, 376 (1927).

201 Powe, supra note 159, at p. 79. 
language of the speaker - the Hand focus on 'objective' words - is the major consideration." ${ }^{202}$ Therefore, mere doctrinal justification of an evil is not in any case punishable ${ }^{203}$.

\section{CONCLUSION}

Both American and Greek jurisprudence are faced with the dilemma of whether hate speech can or cannot be justified by the right to freedom of speech. As is clear from the foregoing analysis, the area concerned is governed in Greece by the Greek anti-racist Law (Article 1(1)), while in the United States the problem is primarily addressed by the Brandenburg Test and the "true threats" doctrine, although the above two doctrines are not adapted to the specific features and requirements of hate speech. For that reason, Professor Martin expresses the view that "on hate speech too, the United States does not provide a good example"204. In fact, courts in the United States seem increasingly unwilling to impose restraints on the freedom of speech ${ }^{205}$. On the other hand, Greece also recognizes the constitutional principle of freedom of expression, but not in an absolute way since Article 14(1) of the Constitution of Greece declares that "[e] very person may express and propagate his thoughts orally, in writing, and through the press in compliance with the laws of the State".

Nevertheless, the comparative analysis showed a convergence of American and Greek legal order on hate speech matters. The Brandenburg principles can be detected in Article 1(1) of the Greek anti-racist Law. Firstly, Brandenburg excludes the mere advocacy of racist beliefs from its scope; similarly, the Greek Law, as well as the Greek case law, adopts the view that the mere dissemination of racist ideas does not, in principle, amount to a criminal offence. Secondly, both legal systems require an "intent to incite" to lawless action. In the author's view, here the Greek legislator seems to grant broader protection to targets of hate rhetoric

202 Gunther, supra note 22, at p. 755.

203 See also Crump, supra note 11, at p. 11 (citing Yates v. United States, 354 U.S. 298 (1957), at p.321).

${ }^{204}$ Martin, supra note 1, at p. 481.

${ }^{205}$ Knechtle, supra note 16, at p. 557. 
by including incitement, not only to violence, but also to discriminating and hateful acts, while Brandenburg is violence-oriented. The Greek choice is welcomed since Pandora's Box remains closed; the key is the public order-proviso. In other words, even inciting to verbal attacks on targets may be punishable, as long as the judge considers that this would be against public policy. Thirdly, incitement to actions should be construed with an open mind so as to cover also indirect or implied (camouflaged) incitement; this admission largely serves the purpose of balancing between freedom of speech and equality rights. Fourth, the Greek legal proviso of "endangerment of public order" is reflected through Brandenburg's 'magic words"206: "imminent lawless action" and "likely to incite or produce such action". These words denote the presence of the famous 'clear and present danger' doctrine in Brandenburg's corpus. Fifth, like Greek jurisprudence, the Brandenburg test not only focuses on the gravity and probability of violence resulting from inflammatory speech, but also looks at the quality and context of the utterance ${ }^{207}$.

Finally, it follows from the above comparison that freedom of expression remains through the hate speech scrutiny unscathed. Both legal systems recognize the freedom of expression as a principal pillar of a democratic society and accept that, in a tolerant democratic society, even extreme anti-democratic views are allowed. Hate speech cannot on its own sanction the freedom of expression, except where the crucial words are directed to inciting racist (and mainly violent) actions in a very dangerous manner. Accordingly, it seems that both legal orders do not share the reasonable concerns of those who view hate speech itself as a direct attack on human value and dignity. Only the imminent likelihood of imperilment of public order may set a limit to the expression of opinion. In that way, a balance of interests between freedom of speech and equality rights is firmly achieved.

${ }^{206}$ For the verbal expression "magic words", see Harry Kalven, JR., A Worthy Tradition: Freedom of Speech in America, New York, Harper \& Row 1988, p. 124.

${ }^{207}$ Crump, supra note 11, at p. 4. 